\title{
Radiotherapy beyond Oncology: Prevention of Heterotopic Ossification - Case study
}

\author{
Ana Lopes, Sara Alves, Tiago Silva, Maria João Paiva, Andreia Neves, Irina Lourenço, Vera Vieira, Sónia Pereira \\ and Inmaculada Maldonado*
}

Radiotherapy Service of Centro Hospitalar Barreiro Montijo, Portugal

Submission: July 23, 2018; Published: August 20, 2018

*Correspondence Address: Inmaculada Maldonado, Radiotherapy Service of Centro Hospitalar Barreiro Montijo, Barreiro, Portugal,

Email: radiot.sec@chbm.min-saude.pt

Abstract

Heterotopic ossification is a biological process characterized by a new bone formation in soft tissue, as muscles and joint capsules. Usually, heterotopic ossification, causes pain, inflammation, decreased range of motion, significantly reducing the quality of life. The radiotherapy is one of the treatments used in heterotopic ossification prophylaxis, since it avoids the ectopic bone formation, inhibiting the development of mesenchymal cells.

Keywords: Radiotherapy; Prevention of heterotopic Ossification

\section{Clinical Case}

A 30-year-old male patient, following a bicycle fall, dislocated and disrupted the triad of the elbow, which underwent a bone repair and was referred for treatment of radiotherapy to prevent heterotopic ossification. He performed external $3 \mathrm{~d}$ conformational radiotherapy and started treatment 24 hours after the surgical procedure. The patient was placed on a lateral decubitus vacuum mattress, and a total dose of 12 Gy was administered in 4 daily fractions (alternating days) of 3 Gy on the elbow. The patient presented good treatment tolerance.

\section{Discussion}

Radiotherapy, in combination with anti-inflammatory drugs, has been shown to be an effective therapy in the prevention of patients at high risk of developing heterotopic ossification. As a reference in the literature, radiotherapy should be administered preoperatively or early postoperatively to prevent heterotopic ossification, and it is recommended that treatment be performed within 72 hours after surgery.

Regarding doses and fractionation, the radiotherapy application in both fractional doses of a total of 12 Gy or in single doses of 6 Gy to 8 Gy is referenced in the literature, and studies have not demonstrated significant differences between single and fractional doses. However, as seen in our case study, single-dose radiotherapy should be more widely preferred because of its ease of application, since we had some difficulties in positioning the patient along the fractions. According to the literature and according to our experience, we can conclude that radiotherapy is not only a therapeutic applied in the oncological forum, presenting promising in the treatment and prophylaxis of benign situations, as is the case of heterotopic ossification. 
Your next submission with Juniper Publishers will reach you the below assets

- Quality Editorial service

- Swift Peer Review

- Reprints availability

- E-prints Service

- Manuscript Podcast for convenient understanding

- Global attainment for your research

- Manuscript accessibility in different formats ( Pdf, E-pub, Full Text, Audio)

- Unceasing customer service

Track the below URL for one-step submission https://juniperpublishers.com/online-submission.php 